\title{
Evaluation of 3 Year Surveillance of Device Associated Infections in a Neonatal Intensive Care Unit
}

\section{Yenidoğan Yoğun Bakım Ünitesinde Alet İlişkili Enfeksiyonların 3 Yıllık Surveyans Değerlendirmesi}

\author{
@Nuran Üstün', @Sibel Özümüt', @Özgül Bulut', @Sertaç Arslanoğlu', @Fahri Ovalı' \\ IIstanbul Medeniyet University, Goztepe Training and Research Hospital, Department of Pediatrics, Division of Neonatology, Istanbul, Turkey
}

\begin{abstract}
Aim: The aim of this study was to determine the rates of healthcare associated infections (HAls) and device associated healthcare associated infections (DA-HAls) as well as the rates of invasive device utilization in a neonatal intensive care unit (NICU); and to compare findings with national and international reports.

Material and Method: A total of 1984 patients who admitted to NICU between January 2016 and December 2018 were enrolled. We retrospectively analysed patient's characteristics, etiologic pathogens and antibiotic susceptibility, mortality from medical charts and infection control committee surveillance reports. Infections were defined using the standart Centers for Disease Control and Prevention criteria.

Results: During the 3-year period, total $98 \mathrm{HAl}$ cases 69 of which were DA-HAI were detected. The overall incidence of HAls was $4.9 \%$ and rate was 3.7 per 1000 patient days. The most common HAl was blood stream infection (BSI) $(n=64,65.3 \%)$ of those 52 were central line-associated (CLA). The CLA-BSI rate was 8.6 per 1000 central line days with central line utilization ratio of 0.22 . Ventilator associated pneumonia (VAP) rate was 5.1 per 1000 ventilator days with ventilator utilization ratio of 0.12 . The most common pathogens were Klebsiella pneumonia. (38.9\%), Staphylococcus epidermidis (22.1\%) and Candida spp. (11.6\%). The overall mortality rate was $3 \%$. The HAI-related mortality rate was $9.2 \%$.

Conclusion: Our findings highlight the importance of an surveillance approach in the NICU setting. HAI rates were lower than the rates reported from developing countries. However, with device utilization rates similar to those in developed countries our HAl rates were higher than that of the developed countries. Continous monitoring and implementation of necessary precautions are essential to decrease the rates of HAls.
\end{abstract}

Keywords: Healthcare-associated infection, device-associated infection, neonatal intensive care unit, surveillance
Öz

Amaç: Hastanemiz yenidoğan yoğun bakım ünitesinde (YYBU) sağlık bakımı ilişkili enfeksiyon (SBIE), alet kullanımı ilişkili enfeksiyon hızlarını ve alet kullanım oranlarını belirlemek; bu sonuçları ulusal ve uluslararası verilerle karşılaştırmak.

Gereç ve Yöntem: Ünitemizde Ocak 2016 ile Aralık 2018 yılları arasında yatan 1984 hasta değerlendirildi. Hastaların demografik ve klinik özellikleri, etyolojik patojenler ve antibiyotik duyarlııkları, mortalite verileri hastane kayıtlarından ve enfeksiyon kontrol komitesi surveyans dosyalarından kaydedilerek retrospektif olarak analiz edildi. Enfeksiyonlar, CDC (Centers for Disease Control) standartları esas alınarak tanımlandı.

Bulgular: 3 yıllık çalışma süresinde, 98 SBiE olgusu saptandı ve bunların 69 (\%70.4)' u alet ilişkili enfeksiyon idi. SBIE insidansı \%4.9 ve hızı her 1000 hasta-yatış günü için 3.7 olarak saptandı. En sık SBIE kan dolaşımı enfeksiyonu (KDE) idi $(n=64, \% 65)$ ve bunların 52'si santral kateter ilişkili enfeksiyon olarak saptandı. SKI-KDE hızı her 1000 kateter günü için 8.6 ve kateter kullanım oranı 0.22 idi. Ventilatiör ilişkili pnömoni (VIP) hızı her 1000 ventilatör günü için 5.1 ve ventilatör kullanım oranı 0.12 idi. En sık izole edilen patojenler Klebsiella pneumonia. (\%38.9), Staphylococcus epidermidis (\%22.1) ve Candida spp. (\%11.6) idi. Toplam mortalite oranı \%3 idi. HKE ilişkili mortalite oranı \%9.2 oranında saptandı.

Sonuç: Bulgularımız YYBU'nde surveyans çalışmasının önemini vurgulamaktadır. Ünitemiz HKE hızları gelişmekte olan ülkelerden düşük olmakla birlikte benzer alet kullanım oranına sahip gelişmiş ülkelerden daha yüksek saptanmıştır. Sürekli monitorizasyon ve gerekli önlemlerin alınması hastane kaynaklı enfeksiyonları azaltacaktır.

Anahtar Kelimeler: Hastane enfeksiyonları, alet ilişkili enfeksiyonlar, yenidoğan yoğun bakım, surveyans

Corresponding (IIletişim): Nuran Üstün, Istanbul Medeniyet University, Goztepe Training and Research Hospital, Department of Pediatrics, Division of Neonatology, Istanbul, Turkey

E-mail (E-posta): nuranustun@yahoo.com

Received (Geliş Tarihi): 29.01.2020 Accepted (Kabul Tarihi): 10.09.2020 


\section{INTRODUCTION}

Healthcare-associated infections (HAls) are significant cause of morbidity and mortality as well as increased cost all over the world. The HAl incidence in neonatal intensive care units (NICUs) has been observed in the range of $1.8 \%$ to $57.7 \%$ in several reports. ${ }^{[1-3]}$ Prematurity, low birth weight, invasive procedures including catheterisation and mechanical ventilation, prolonged hospitalisation, use of wide spectrum antibiotics are important factors related to HAls in neonates. $[4,5]$ The majority of HAls are device-associated healthcareassociated infections (DA-HAls) because of insufficient immune system, mechanical barriers and protective flora of newborn infants. ${ }^{[6]}$

Active surveillance is well established method to determine the $\mathrm{HAl}$ rates, identify risks and problems and evaluate the necessary precautions to reduce frequency of HAls. ${ }^{[7,8]}$ Surveillance of DA-HAls and device utilization are important to assess the infection rate according to with device utilization. The characteristics and rates of HAls, and device utilization has been shown to be different between developing and developed countries. ${ }^{[9]}$

The aim of this study was to determine incidence of $\mathrm{HAl}$; evaluate DA-HAls rates and device utilization ratiosin in a NICU. In addition, we compared our results with the current national and international data.

\section{MATERIALS AND METHODS}

Our NICU is a tertiary care NICU with 35 incubators and 20 ventilators. The NICU staff consist of 2 neonatology specialists, 5 pediatric residents, one nurse per 3 level III infants and one nurse per 5-6 level I-II infants. Our unit admits inborn neonates from the Obstetric Department (approximately 2500 births per year) and outborns tranported from different hospitals.

This study was a retrospective analyses of neonates admitted to our NICU between January 1, 2016 and December 30, 2018. Infants who were discharged or died 48 hours after admission were excluded. This study was approved by Medeniyet University, Goztepe Training and Research Hospital, Ethics Committee on Nowember 20, 2019 with decision number: 2019/0332.

Active surveillance of HAls was carried out by infection control committee including an infectious disease specialist and trained nurses. During the hospitalization period, infection control nurses recorded patient information on daily basis. The diagnosis of HAI was made based on criteria of $\mathrm{CDC} .{ }^{[10]}$ Blood stream infection (BSI) was defined as one or more positive blood cultures with no identified source. BSI was categorized as central line associated (CLA) in case of a central catheter was in place within \pm 2 days of positive blood culture. Pneuomonia was categorised as ventilator associated pneumonia (VAP) that developed during or within 48 hours after mechanical ventilation.
The following calculated parameters were used to evaluate HAls: ${ }^{[11,12]}$

HAl incidence: number of HAls / number of patients $x 100$

HAl rate: number of HAls / patient-days $\times 1000$

CLA-BSI rate: number of CLA-BSI / central line days $x 1000$

Central line utilization ratio: Central line days / patient-days

VAP rate: number of VAP / ventilator days $x 1000$

Ventilator utilization ratio: Ventilator days / patient-days

We compared the results of our study with the National Infection Surveillance and Control Unit (UHESA) report (2017), the International Nosocomial Infection Control Consortium (INICC) report (2010-2015) as well as the United States National Healthcare Safety Network (NHSN) report (2013). ${ }^{[12-14]}$

The data were analysed with SPSS for Windows 22.0. The chi square test was used. Mean \pm standart deviation and precentages were presented. Chi-square test and Fisher's exact test were performed to find differences between groups. A p value $<0.05$ was considered as sinificant.

\section{RESULTS}

During 3-year study period, 1984 patients which represents 26554 patient days were enrolled. Total of $98 \mathrm{HAl}$ cases were detected in 81 patients of which 13 had multiple HAls. The overall HAI incidence was $4.9 \%$ and rate was 3.7 per 1000 patient days. The most common HAI was BSI (65.3\%) followed by VAP (17.3\%). The distribution of HAls according to infection sites are presented in Table 1.

\begin{tabular}{|c|c|c|c|c|}
\hline & $\mathbf{n}$ & $\%$ & $\begin{array}{c}\text { Rate per } 100 \\
\text { patients }\end{array}$ & $\begin{array}{c}\text { Rate per } 1000 \\
\text { patient-days }\end{array}$ \\
\hline BSI & 64 & 65.3 & 3.22 & 2.41 \\
\hline VAP & 17 & 17.3 & 0.85 & 0.06 \\
\hline CNS Infections & 6 & 6.1 & 0.30 & 0.02 \\
\hline $\begin{array}{l}\text { Skin and soft } \\
\text { tissue infections }\end{array}$ & 4 & 4.1 & 0.20 & 0.01 \\
\hline $\begin{array}{l}\text { Surgical site } \\
\text { infections }\end{array}$ & 4 & 4.1 & 0.20 & 0.01 \\
\hline $\begin{array}{l}\text { Urinary tract } \\
\text { infections }\end{array}$ & 3 & 3.1 & 0.15 & 0.01 \\
\hline Total & 98 & 100 & 4.93 & 3.69 \\
\hline
\end{tabular}

52 of $64(81 \%)$ BSI episodes were related to central catheter use and overall CLA-BSI rate was 8.6 per 1000 central line days with central line utilization ratio of 0.22 . The VAP rate was 5.8 per 1000 ventilator days with ventilator utilization ratio of 0.12 . The annual rate of CLA-BSI were found to vary whereby VAP rate did not change wtihin 3-year study period. Central catheter and ventilator utilization ratios in each year were similar $(0.22,0.21,0.25$ and $0.13,0.12,0.13$, respectively). The highest CLA-BSI rate (11.5 per 1000 catheter days) was observed in 2016 and decreased to 5.5 per 1000 catheter days in 2017 (Figure 1). 


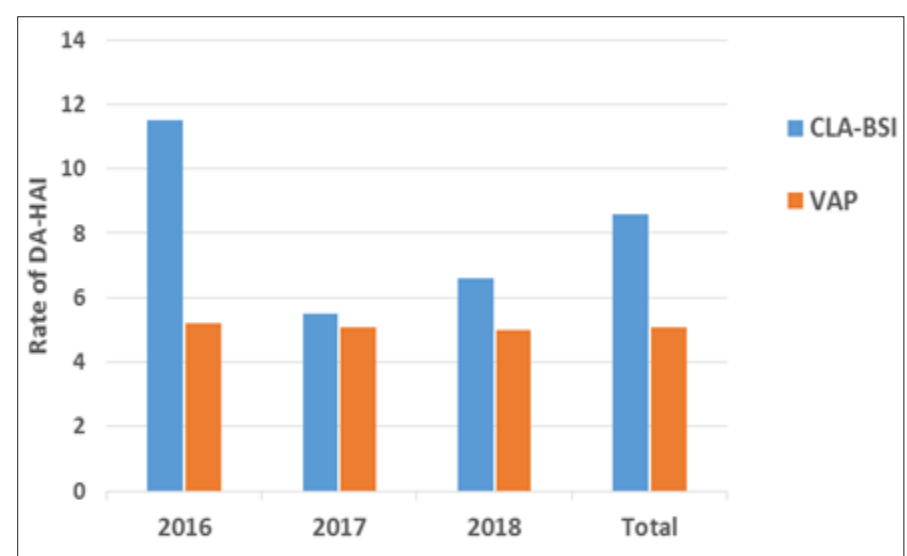

Figure 1. The rates of device-associated nosocomial infections over the 3-year period.

CLA-BSI, central line-associated blood stream infections; VAP, ventilator-associated pneumonia

Table 2 summarizes the CLA-BSI rate and central line utilization ratio of study group and the results national and international reports. Central lines were most commonly used in patients with birth weight less than $1500 \mathrm{~g}$. Of 52 CLA-BSI cases, 50 (96\%) were preterm and 45 (86.5\%) were very low birth weight $(<1500 \mathrm{~g})$ infants. Infection was diagnosed averagely on $20.2 \pm 8.4$ (10-54) days after catheter insertion.

Table 3 summarizes the VAP rate and ventilator utilization ratio of study group and the results national and international reports. The highest VAP rate and ventilator utilization was observed in $\leq 750 \mathrm{~g}$ birth weight class. All VAP cases were preterm infants. VAP was detected averagely on day $28.3 \pm 17.2$ (4-75) of mechanical ventilation.
The distribution of isolated microorganisms from HAls were shown in Table 4. The most common organisms were Klebsiella pneumonia. (38.9\%), Staphylococcus epidermidis (22.1\%) and Candida spp. (11.6\%). Resistance rates of Klebsiella pneumonia to the antimicrobial agents, respectively, were as follows: gentamicin 52\%; carbapenem 33\%; colistin 20\%; ciprofloxacin 24\%, trimethoprim-sulfamethoxazole 20\%; ESBL production of Klebsiella spp. was found as 64\%. All strains were susceptible to tigecycline. Of the Staphyloccocus spp. $68 \%$ were resistant to methicilline and cephalothin. There was no vancomycin resistant strain in Gram positive pathogens. Candida spp. were susceptible to amphotericin B, and ekinokandins.

\begin{tabular}{lcc} 
Table 4. Distribution of causative agents in HAI (2016-2018) & \\
Microorganism types & $\mathbf{n}$ & $\%$ \\
\hline Klebsiella pneumonia & 37 & 38.9 \\
Staphylococcus epidermidis & 21 & 22.1 \\
Candida spp & 11 & 11.6 \\
Enterobacter spp. & 5 & 5.3 \\
Staphylococcus aureus & 4 & 4.2 \\
Acinetobacter baumannii & 6 & 6.3 \\
Serratia marcescens & 4 & 4.2 \\
Enterococcus faecium & 3 & 3.2 \\
Pseudomonas aeuriginosa & 4 & 4.2 \\
Total & 95 & 100 \\
\hline
\end{tabular}

HAI, healthcare-associated infection; $n$, number

Table 2. Comparison of central line utilization ratios and CLABSI rates of our hospital NICU with national and international data

\begin{tabular}{|c|c|c|c|c|c|c|c|c|c|c|c|c|}
\hline \multirow[b]{2}{*}{$\begin{array}{l}\text { Birth-weight } \\
\text { category }\end{array}$} & \multirow[b]{2}{*}{$\begin{array}{c}\text { Patient } \\
\text { number }\end{array}$} & \multirow[b]{2}{*}{$\begin{array}{c}\text { Patient } \\
\text { days }\end{array}$} & \multirow[b]{2}{*}{$\begin{array}{l}\text { Central- } \\
\text { line days }\end{array}$} & \multirow[b]{2}{*}{$\begin{array}{c}\text { CLABSI } \\
\text { (n) }\end{array}$} & \multicolumn{4}{|c|}{ Central line utilization ratio } & \multicolumn{4}{|c|}{ CLABSI rate } \\
\hline & & & & & $\begin{array}{c}\text { Our NICU } \\
(2016- \\
2018)\end{array}$ & $\begin{array}{l}\text { UHESA } \\
(2017)\end{array}$ & $\begin{array}{l}\text { INICC } \\
(2010- \\
2015)\end{array}$ & $\begin{array}{l}\text { NHSN } \\
(2013)\end{array}$ & $\begin{array}{c}\text { Our NICU } \\
(2016- \\
2018)\end{array}$ & $\begin{array}{l}\text { UHESA } \\
(2017)\end{array}$ & $\begin{array}{l}\text { INICC } \\
(2010- \\
2015)\end{array}$ & $\begin{array}{l}\text { NHSN } \\
(2013)\end{array}$ \\
\hline Total & 1984 & 26554 & 6069 & 52 & 0.22 & 0.16 & 0.29 & 0.26 & 8.6 & 2.2 & 12.7 & 1.5 \\
\hline$\leq 750 \mathrm{gr}$ & 44 & 2575 & 1479 & 13 & 0.57 & 0.40 & 0.45 & 0.39 & 8.8 & 3.3 & 18.3 & 2.1 \\
\hline $751-1000 \mathrm{gr}$ & 39 & 1798 & 868 & 10 & 0.48 & 0.32 & 0.44 & 0.33 & 11.5 & 2.9 & 14.5 & 1.3 \\
\hline $1001-1500 \mathrm{gr}$ & 119 & 4496 & 1661 & 22 & 0.36 & 0.23 & 0.33 & 0.26 & 13.2 & 2.4 & 15.3 & 0.8 \\
\hline $1501-2500 \mathrm{gr}$ & 372 & 6044 & 990 & 4 & 0.16 & 0.13 & 0.21 & 0.17 & 4.0 & 2 & 7.7 & 0.6 \\
\hline$>2500 \mathrm{gr}$ & 1410 & 11641 & 1071 & 3 & 0.09 & 0.11 & 0.22 & 0.23 & 2.8 & 1.7 & 9.3 & 0.7 \\
\hline
\end{tabular}

Table 3. Comparison of our ventilator utilization ratios and VAP rates withnational and international data

\begin{tabular}{|c|c|c|c|c|c|c|c|c|c|c|c|}
\hline \multirow[b]{2}{*}{$\begin{array}{l}\text { Patient } \\
\text { number }\end{array}$} & \multirow[b]{2}{*}{$\begin{array}{c}\text { Patient } \\
\text { days }\end{array}$} & \multirow[b]{2}{*}{ MV days } & \multirow[b]{2}{*}{$\operatorname{VAP}(\mathbf{n})$} & \multicolumn{4}{|c|}{ Ventilator utilization ratio } & \multicolumn{4}{|c|}{ VAP rate } \\
\hline & & & & $\begin{array}{c}\text { Our NICU } \\
(2016- \\
2018)\end{array}$ & $\begin{array}{l}\text { UHESA } \\
(2017)\end{array}$ & $\begin{array}{l}\text { INICC } \\
(2010- \\
2015)\end{array}$ & $\begin{array}{l}\text { NHSN } \\
(2013)\end{array}$ & $\begin{array}{c}\text { Our NICU } \\
\text { (2016- } \\
2018)\end{array}$ & $\begin{array}{l}\text { UHESA } \\
(2017)\end{array}$ & $\begin{array}{l}\text { INICC } \\
(2010- \\
2015)\end{array}$ & $\begin{array}{l}\text { NHSN } \\
(2013)\end{array}$ \\
\hline 1984 & 26554 & 3346 & 17 & 0.12 & 0.19 & 0.23 & 0.21 & 5.1 & 1.1 & 7.5 & 0.6 \\
\hline 44 & 2575 & 1265 & 8 & 0.49 & 0.49 & 0.48 & 0.38 & 6.3 & 1.8 & 3.3 & 1.0 \\
\hline 39 & 1798 & 350 & 1 & 0.19 & 0.37 & 0.32 & 0.22 & 2.8 & 1.4 & 4.9 & 1.1 \\
\hline 119 & 4496 & 736 & 6 & 0.16 & 0.24 & 0.20 & 0.10 & 8.1 & 1.1 & 13.2 & 0.7 \\
\hline 372 & 6044 & 511 & 2 & 0.08 & 0.17 & 0.18 & 0.06 & 3.9 & 0.8 & 6.4 & 0.5 \\
\hline 1410 & 11641 & 484 & 0 & 0.04 & 0.15 & 0.23 & 0.10 & 0 & 1 & 5.5 & 0.1 \\
\hline
\end{tabular}


During 3-year study period, the overall mortality rate was $3 \%$ in our NICU. The all HAl-related mortality rate was $9.2 \%$. Mortality rate was $11.5 \%$ for CLA-BSI and $17.6 \%$ for VAP cases. The crude rates for excess mortality associated with HAls, CLA-BSI and VAP were determined as $6.1 \%, 7.7 \%$ and $11.8 \%$, respectively.

\section{DISCUSSION}

Advances in neonatal care have inreased survival rates of prematüre, low birth weight but HAls are still significant and unsolved problem in NICUs. Monitoring the HAI rates is an significant part of high quality healthcare, especially in NICUs. Therefore, we evaluated infection surveillance of our NICU and compared it with values in national and international reports.

The HAl incidences in literature vary between $1.8 \%$ to $57 \%$ with higher rates in developing countries. ${ }^{[2,9]}$ In a study from Egypt, HAl rate was reported as $21.4 \%{ }^{[15]}$ In studies from Brazil, reported rateof HAls ranged between $18.3 \%$ to $50.7 \% .{ }^{[1,17]}$ Studies from Europe have reported rates varying between $1.6 \%$ to $13.2 \% \cdot{ }^{[19]}$ In a multicenter study from Turkey, $\mathrm{HAI}$ rate ranged between $2.1 \%$ and $17 \% .{ }^{[20]}$ In studies from Turkish NICUs, $\mathrm{HAl}$ rate was varied between $8 \%$ to $29.7 \% .{ }^{[21-23]}$ In our study, the overall incidence HAI was $4.9 \%$ which was consistent with other studies. Variations in reported HAI rates were considered as a result of differences in clinical practices, demographic factors and resource utilities in NICUs.

BSIs are reported as the most common HAls worldwide. ${ }^{[24,25]}$ In our study, the most frequent HAls were BSIs (65.3\%) followed VAP (17.3\%). The rates of DA-HAls differ in terms of sites of infection. In studies from developed countries, CLA-BSIs are the most common DA-HAls whereas VAPs have been reported as major DAls in studies from developing countries. ${ }^{[6,9]}$ Previous studies from Turkey have reported that VAP accounts almost $80 \%$ of all DAls in NICUs. ${ }^{[20-22,27]}$ In our study, CLA-BSI was the most frequent (75.4\%) DAls followed by VAP (24.6\%). These differences can be explained by changes in ventilatory management and central catheter care practices.

The CLA-BSI rate was reported as $2.6-18.3 \%$ from different Turkish NICUs. ${ }^{[2,23,27]}$ In INICC study, involving 703 centers from 50 countries, CLA-BSI rate was $12.7 \%$ with catheter utilization ratio of $0.29 .{ }^{[13]} \mathrm{CLA}-\mathrm{BSI}$ rate was 8.6 per 1000 central line days with central line utilization ratio of 0.22 . Our CLA-BSI rate was lower than that reported INICC study with similar catheter utilizaiton ratio. ${ }^{[13]}$ In previous studies from Turkish NICUs, the VAP rate was ranging $6.4-17 \% 0^{[22,23,27]}$ The VAP rate was $7.5 \%$ with ventilator utilization of 0.23 in the INICC report. ${ }^{[13]}$ Our VAP rate lower than that reported INICC study with lower ventilator utilization ratio. ${ }^{[13]}$ When compared to data of NHSN from US, although device utilization ratios were similar, the rates of CLA-BSI and VAP were higher in our study. ${ }^{[14]}$ The findings our study showed us our rates were lower than the those reported from developing countries but in significant level. In order to decrease the device associated infections, we evaluated our catheter care and ventilator management principles and took urgent precautions.
The risk factors related to HAls include prematurity, low birth weight, mechanical ventilation, central catheter, use of wide spectrum antibiotics, $\mathrm{H} 2$ blockers and steroids. ${ }^{[25]}$ Low birth weight infants $(<1500 \mathrm{~g})$ have 3 times higher risk for nosocomial infections. ${ }^{[26]}$ In our study, most of the CLA-BSIs and VAPs were diagnosed in infants with birth weight less than $1500 \mathrm{~g}$ which was consistent with previous studies. In addition, we observed that prolonged mechanical ventilation and central catheter duration were associated with VAP and CLA-BSI, respectively, accordance with literature. ${ }^{[6,22,27]}$

The most common pathogens are Gram positive pathogens especially coagulase negative staphylococcus spp. in developed countries whereas Gram negative pathogens are found to be major causative pathogens in developing countries. ${ }^{[24,28,29]}$ In our study, the most frequent pathogens isolated from HAl cases were Klebsiella spp, which is consistent with previous studies. ${ }^{[20,24]}$

It has been known that HAls are significantly associated with mortality, especially in low birth weight infants. HAI related mortality was $9.2 \%$ of which VAP has the highest rates (17.6\%) in our NICU. Our rates were lower than those reprted in previous studies. ${ }^{[13,20,29]}$ On the other hand, since patients without HAI have a lower mortality rate (3\%) than those with nosocomial infection, it seems like we should continue to focus on preventive strategies to reduce HAls such as limiting the use of devices in our NICU.

\section{CONCLUSION}

Our study showed that the nosocomial infections was a important problem in our NICU. Reducing HAI rates requires a well -organized infrastructure as well as continuous education of the staff and the unit culture and policies on patient care. Fast turnover of staff, especially of nurses hinders the growth of a unit culture and frequent use of antibiotics mostly within the context of defensive medicine considerations complicates the problem.

\section{ETHICAL DECLARATIONS}

Ethics Committee Approval: This study was approved by Medeniyet University, Goztepe Training and Research Hospital, Ethics Committee on Nowember 20, 2019 with decision number: 2019/0332.

Informed Consent: Because the study was designed retrospectively, no written informed consent form was obtained from patients.

Referee Evaluation Process: Externally peer-reviewed.

Conflict of Interest Statement: The authors have no conflicts of interest to declare.

Financial Disclosure: The authors declared that this study has received no financial support.

Author Contributions: All of the authors declare that they have all participated in the design, execution, and analysis of the paper, and that they have approved the final version. 


\section{REFERENCESS}

1. Moore DL. Nosocomial infections in newborn nurseries and neonatal intensive care units. In: Mayhall CG (ed). Hospital epidemiology and infection control. Baltimore:Williams-Wilkins, 1996:535-64.

2. Couto RC, Pedrosa TM, Tofani Cde P, Pedrosa ER. Risk factors for nosocomial Infection in a neonatal intensive care unit. Infect Control Hosp Epidemiol 2006;27:571-5.

3. Hacımustafaoglu M, Celebi S, Koksal N, Kavurt S, Ozkan H, Cetinkaya M, et al. Nosocomial infections in neonatology clinic and neonatal intensive care unit. Turk Arch Ped 2011;46:302e7.

4. Goldmann DA, Durbin WA Jr, Freeman J. Nosocomial infections in a neonatal intensive care unit. J Infect Dis. 1981;144(5):449-59.

5. Edwards JR, Peterson KD, Mu Y, et al. National Healthcare Safety Network (NHSN) report:data summary for 2006 through 2008, issued December 2009. Am J Infect Control. 2009;37(10):783-805.

6. Polin RA, Denson S, Brady MT. Epidemiology and Diagnosis of Health Care-Associated Infections in the NICU. the COMMITTEE ON FETUS AND NEWBORN INFECTIOUS DISEASES. Pediatrics 2012;129;e1104

7. Garner JS, Jarvis WR, Emori TG, Horan TC, Hughes JM. CDC definitions for nosocomial infections. Am J Infect Control 1988;16:128e40.

8. Haley RW, Quade D, Freeman HE, Bennett JV. The SENIC Project. Study on the Efficacy of Nosocomial Infection Control (SENIC Project). Summary of study design. Am J Epidemiol 1980;111:472e85.

9. Allegranzi B, Bagheri Nejad S, Combescure C, et al. Burden of endemic health-care-associated infection in developing countries:systematic review and meta-analysis. Lancet 2011;377:228-41.

10. CDC definitionof health-care associated infection2015.Available at:www. cdc.gov/nhsn/PDFs/pscManual/2PSC_IdentifyingHAls_NHSNcurrent. pdf. Accessed February 7, 2019.

11. Emori TG, Culver DH, Horan TC, Jarwis WR, White JW, Olson DR, Banerjee S, Edwards JR, Martone WJ, Gaynes RP. National nosocomial infections surveillance system (NNIS):description of surveillance methods. Am J Infect Control 1991;19:19-35.

12. Public Health Institution of Turkey, Department of ContagiousDiseases, National Nosocomial Infections Surveillance System,Summary Report;(Halk Sağlığı Genel Müdürlüğü, Bulaşıcı HastalıklarDairesi Başkanlığı, Ulusal Sağlık Hizmeti İliş̧kili EnfeksiyonlarSürveyans Ağı Özet Raporu) 2017. Available at:http://hsgm.saglik.gov.tr

13. Rosenthal VD, Al-Abdely HM, El-Kholy AA, et al;Remaining authors. International Nosocomial Infection Control Consortium report, data summary of 50 countries for 2010-2015:deviceassociated module. Am J Infect Control 2016;44(12):1495-504.

14. Dudeck MA, Edwards JR, Allen-Bridson K, et al. National Healthcare Safety Network report, data summary for 2013, deviceassociated module. Am J Infect Control 2015;43(03):206-21.

15. Gadallah MAH, Fotouh AMA, Habil I.S, Wassef I.G. Surveillance of health care associated infections in a tertiary hospital neonatal intensive care unit in Egypt:1-year follow-up Am J Infect Control, 42 (November (11)) (2014), pp. 1207-11.

16. Fortaleza M.C.B, Padoveze M.C, Kiffer R.V. Multi-state survey of healthcareassociated infections in acute care hospitals in Brazil. Journal of Hospital Infection 2017;96 139e144.

17. Efird MM, Rojas MA, Lozano JM, et al. Epidemiology of nosocomial infections in selected neonatal intensive care units in Colombia, South America. J Perinatol 2005;25:531e536.

18. Zingg W, Hopkins S, Gayet-Ageron A, et all. Health-care-associated infections in neonates, children, and adolescents:an analysis of paediatric data from the European Centre for Disease Prevention and Control pointprevalence survey. Lancet Infect Dis. 2017 Apr;17(4):381-9.

19. Turkish Neonatal Society, Nosocomial Infections Study Group. Nasocomial infections in neonatal units in Turkey:epidemiology problems, unit policies and opinions of healthcare workers. Turk J Pediatr 2010;52:50-7.
20. Yapicioglu H, Satar M, Ozcan K, et al. A 6-year prospective surveillance of healthcare-associated infections in a neonatal intensive care unit from southern part of Turkey. J Paediatr Child Health 2010;46:337-42.

21. Tekin R, Dal T, Pirinccioglu H, Oygucu SE. A 4-year surveillance of deviceassociated nosocomial infections in a neonatal intensive care unit. Pediatr Neonatol. 2013;54(5):303-8.

22. Kilic A, Okulu E, Kocabas BA, Alan S, Cakir U, Yildiz D et al. Health careassociated infection surveillance:A prospective study of a tertiary neonatal intensive care unit. J Infect Dev Ctries 2019;13(3):181-7.

23. Sohn AH, Garrett DO, Sinkowitz-Cochran RL, et al. Prevalence of nosocomial infections in neonatal intensive care unit patients:results from the first national point-prevalence survey. J Pediatr 2001;139:821e827.

24. Urrea $M$, Iriondo $M$, Thio $M$, et al. A prospective incidence study of nosocomial infections in a neonatal care unit. Am J Infect Control 2003;31:505e507.

25. Foglia E, Meier MD, Elward A. Ventilator associated pneumonia in neonatal and pediatric intensive care unit patients. Clin Microbiol Rev 2007;20(3):409-25.

26. Yalaz M, Altun-Koroglu O, Ulusoy B, Yıldız B, Akisu M, Vardar F, et al. Evaluation of device-associated infections in a neonatal intensive care unit. Turk J Pediatr 2012;54:128e35.

27. Isaacs D. A ten years multicenter study of coagulase negative staphylococcal infections in Australian neonatal units. Archs Dis Childh Fetal Neonatal Ed 2003;88:89e93.

28. Srivastava S, Shetty N. Healthcare-associated infections in neonatal units:lessons from contrasting worlds. J Hosp Infect 2007;65:292-306.

29. Abdel-Wahab F, Ghoneim M, Khashaba M, El-Gilany AH, Abdel-Hady D (2013) Nosocomial infection surveillance in an Egyptian neonatal intensive care unit. J Hosp Infect 83:196-9. 